\title{
Aqueous Extract Of Camellia Sinuses Shows Immunological And Histological Changes In Induced Inflammatory Animal Models
}

\author{
Maha G. Soliman \\ Department of pharmacology (Medical microbiology and immunology unit) \\ National organization for drug control and research
}

\begin{abstract}
The present study investigated the effect of green tea (Camellia sinuses) aqueous extract on the inflammatory response induced by Carrageenan (CGN) (1\%) in Sprague dawaly rats. 48 rats were equally divided into 6 groups:control, green tea drinking, Carrageenan $(1.2 \%)$ treated for 24 hours, green tea - Carrageenan treated for 24 hours, CGN treated for 72 hours, green tea - CGN treated for 72 hours. On the last day of drinking green tea aqueous extract, inflammation was induced to rats by Carrageenan . Twenty-four and seventy-two hours after CGN challenge, blood samples were withdrawn and animals were sacrificed. Animals which were injected with CGN had shown highly significant leucocytosis, monocytosis and eosinophilia. More reticuloendothelial organ damages like severe inflammation, cellular lymphocytic infilteration and congestion were distinguished in 72 hours animal group. Green teadrinking and CGN treated groups showed a significant improvement in reticuloendothelial organs such as thymus gland, spleen and liver. A histopathological improvement of these organs was observed in green tea and CGN 72 hours treated group more than that group which treated for 24 hours. This group showed also a significant drop in total leucocyte count and peritoneal fluid neutrophils while a significant increase of bone marrow lymphocyte count was observed when compared with the CGN treated animal group. A significant modulation in differential leucocytic count especially the drop in lymphocytic and eosinophilic percentage occurred. This was associated with lower serum globulin and immunoglobulin $\mathrm{G}(\mathrm{IgG})$ in green teadrinking-CGN treated animal group in comparison to CGN treated animal groups. This study explains the immunomodulatory role played by green tea in response to inflammatory immunostimulant agent.
\end{abstract}

\section{Introduction}

There is growing interest in the role of complementary and alternative medicine in health and disease. Of the various herbal and botanical agents used, tea (Camellia sinusis) has drawn a great deal of interest (Gary et al., 2001). Green tea is widely used in Asia and has also become popular in Western countries. (Hofbauer et al., 1999). It is cultivated in more than 30 countries (Mokhtar and Ahmed , 2000). Green tea is potent antioxidant, It has both anticancer and anti-inflammatory effects (Fajun et al., 1998).

Lau et al., (2002), evaluated the anti-inflammatory and hepato-protective activities of the green tea. The epidem iologic observations and laboratory studies have indicated that polyphenolic compounds present in tea may reduce the risk of a variety of illnesses (Mokhtar and Ahmed, 2000). Zhu et al. 
(1999), concluded that tea and its components ameliorate immune disfunction in mice bearing Lewis lung carcinoma since all immune functions were improved accompanied by inhibition of tumor growth, while in 1998, Zhu et al., concluded that green tea or its components showed a significant protection from early adverse changes in immune functions. Gary et al. (2001), postulated that green tea and its polyphenol fracture were useful dietary supplement in the treatement of some chronic inflammatory diseases.

Suganuma et al. (1996), stated that green tea anti-inflammatory effects may be possibly mediated through their antioxidant properties, while Chan et al. (1995), observed that green tea also inhibited production in peritoneal exudates (macrophage) cells. Similarly lin and lin (1997), showed that green tea inhibited lipopolysaccharide stimulated nitric oxide production and inducible nitric oxide synthesis gene expression in peritoneal macrophages by decreasing nuclear factor -B.

Its clear that green tea polyphenols have anti-inflammatory effects, antioxidant properties and inhibited tumor necrosis factor induction in macrophages by attenuating nuclear factor activation.

This study is a try to detect the anti-inflammatory effect of green tea in different reticuloendothelial organs in treated rats with carrageenan.

\section{Material And Methods Animals.}

Fourty eight male Sprague dawely rats weighing between 160-210 gms, each were used in the present study. The animals were obtained from the animal house of NODCAR (National Organization For Drug Control And Research). The animals were divided into the following groups :
1. Control group : Untreated water drinking animals .

2. Green tea drinking group (1.2\%): Rats were randomly assigned to receive green tea water extract as drinking for four weeks (Arteel et al., 2002).

3. Carrageenan (CGN)treated group $(1 \%)$ : rats were injected intraperitonealy for 24 hours (Nacife, et al., 2000).

4. Carrageenan treated group (1\%): rats were injected intraperitoneal for 72 hours (Ghosh et al., 2000).

5. Green tea-Carrageenan treated group for 24 hours: at the last day of drinking green tea, animals were injected with CGN interaperitonealy and then after 24 hours of injection , blood samples were withdrown and animals were sacrificed.

6. Green tea-Carrageenan treated group for 72 hours: at the last day of drinking green tea animals were injected with CGN and then after 72 hours of injection blood samples were withdrown before sacrificing.

After 24 and 72 hours of Carrageenan treated groups, blood samples were withdrawn for determination of total protein, albumin and globulin serum concentrations (using Randox chemicals). Also IgG level was determined using immunodiffusion plates (NANORID), The Binding site, Birmingham, UK. Then all rats were sacrificed, samples were withdrawn from the peritoneal fluid for both total and differential counting. Liver, spleen and thymus gland were obtained for recording their weights and histopathological studies. For light microscopy liver,spleen and thymus gland were fixed in Bouin's fluid, dehydrated in ascending grades of alcohol, cleared in xylol and embeded in paraffin. Sections,5-6 micrometer thick were cut mounted and stained with haematoxy- 
line and eosin. Bone marrow smears from femur were obtained for bone marrow lymphocytic count. All differential counts were carried out using leishman's stain. Results were evaluated using T-student test.

Table (1): Body and lymphoid and non-lymphoid organ weights from green tea drinking and Carrageenan-treated rats.

\begin{tabular}{|c|c|c|c|c|}
\hline Animal group & $\begin{array}{l}\text { Body weigh } \\
\text { (g) }\end{array}$ & $\begin{array}{l}\text { Thymus weight } \\
\text { (\% of body weight) }\end{array}$ & $\begin{array}{c}\text { Spleen weight } \\
\text { ( \%of body weight) }\end{array}$ & $\begin{array}{l}\text { Liver weight } \\
\text { (\%of body } \\
\text { weight) }\end{array}$ \\
\hline Control & $178 \quad \pm 1.4$ & $0.16 \pm 0.01$ & $0.48 \pm 0.02$ & $3.8 \pm 0.20$ \\
\hline Green tea drinking & $197 \pm 9.4$ & $0.15 \pm 0.01$ & $0.46 \pm 0.05$ & $3.9 \pm 0.35$ \\
\hline $\begin{array}{c}\text { Carrageenan for } 24 \\
\text { hours }\end{array}$ & $152 \pm 3.8$ & $\begin{array}{c}0.19+0.02 \\
*\end{array}$ & $\begin{array}{c}0.62 \pm 0.06 \\
\mathrm{o}^{*}\end{array}$ & $4.1 \pm 0.14$ \\
\hline $\begin{array}{c}\text { Green } \\
\text { tea+Carrageenan for } \\
24 \text { hours }\end{array}$ & $\begin{array}{c}219 \pm 7.7 \\
* \\
\ldots, \text { oo }\end{array}$ & $0.15+0.004$ & $0.53 \pm 0.02$ & $4.1 \pm 0.17$ \\
\hline $\begin{array}{l}\text { Carrageenan for } \\
72 \text { hours }\end{array}$ & $159+8.1$ & $0.16 \pm 0.12$ & $0.82 \underset{\substack{* * * \\
\text { ooo }}}{+} 0.09$ & $\begin{array}{l} \pm 0.34 \\
*\end{array}$ \\
\hline $\begin{array}{c}\text { Green } \\
\text { tea+Carrageenan } \\
\text { For } 72 \text { hours }\end{array}$ & $205 \underset{*}{ \pm} 7.4$ & $0.15 \pm 0.01$ & $\begin{array}{c}0.71 \underset{* * *}{ \pm} 0.02 \\
\text { ooo }\end{array}$ & $\begin{array}{c} \pm 0.12 \\
* \\
0\end{array}$ \\
\hline
\end{tabular}

Table (2): Peripheral blood haematological findings from green tea drinking and Carrageenan treatment.

\begin{tabular}{|c|c|c|c|c|c|}
\hline Animal group & $\begin{array}{c}\text { Total } \\
\text { Leucocyt. } \\
\text { Count/cmm }\end{array}$ & $\begin{array}{l}\text { Lymphocytes } \\
(\%)\end{array}$ & $\begin{array}{l}\text { Neutrophils } \\
(\%)\end{array}$ & $\begin{array}{c}\text { Monocytes } \\
(\%)\end{array}$ & $\begin{array}{c}\text { Eosinopils } \\
\%\end{array}$ \\
\hline Control & $7725 \pm 982$ & $58 \pm 1.1$ & $39 \pm 1.2$ & $1.8 \pm 0.3$ & $1.2 \pm 0.3$ \\
\hline Green tea drinking & $8631 \pm 961$ & $64 \pm 4.0$ & $33 \pm 4.5$ & $1.5 \pm 0.4$ & $0.7 \pm 0.5$ \\
\hline Carrageenan for 24 hours & $\begin{array}{c}19330 \pm 1699 \\
* * * \\
\text { ооо }\end{array}$ & $58 \pm 4.6$ & $40 \pm 4.7$ & $\begin{array}{l} \pm 0.3 \\
* * *\end{array}$ & $\pm \underset{*}{0.2}$ \\
\hline $\begin{array}{c}\text { Green tea+Carrageenan for } \\
24 \text { hours }\end{array}$ & $\begin{array}{c}12850 \pm 1645 \\
* * * \\
\ldots, \text { ооо }\end{array}$ & $59 \pm 8.1$ & $36 \pm 7.6$ & $2.1 \pm 0.5$ & $0.7 \pm 0.4$ \\
\hline $\begin{array}{l}\text { Carrageenan for } \\
72 \text { hours }\end{array}$ & $\begin{array}{c}28742 \pm 2603 \\
* * * \\
\text { oоo } \\
\end{array}$ & $68+7.6$ & $24+\frac{ \pm}{*} 7.7$ & $\begin{array}{c}5.0+1.2 \\
* * *\end{array}$ & $\begin{array}{c}3.0 \pm 0.46 \\
* * * \\
\ldots, 000\end{array}$ \\
\hline $\begin{array}{c}\text { Green tea }+ \text { Carrageenan for } \\
72 \text { hours }\end{array}$ & $\begin{array}{c}16090 \pm 4849 \\
* * * \\
\ldots, \text { oоo }\end{array}$ & $65 \pm 7.7$ & $30 \pm 6.5$ & $\begin{array}{c}0.6 \pm 0.4 \\
* * \\
\ldots, \mathrm{o}\end{array}$ & $\begin{array}{l}+0.1 \\
* * * \\
. ., 000\end{array}$ \\
\hline
\end{tabular}

$*, * *, * * * \quad$ Significance at $\mathrm{P}<0.05,0.01$ and 0.001 respectively when compared with control group

o,oo,ooo Significance at $\mathrm{P}<0.05,0.01$ and 0.001 respectively when compared with green tea drinking group .

Significance at $\mathrm{P}<0.05,0.01$ and 0.001 respectively when compared with Carrageenan treated groups 
Table (3): Peritoneal fluid haematological findings from green tea drinking and Carrageenan treatment.

\begin{tabular}{|c|c|c|c|c|c|}
\hline Animal group & $\begin{array}{c}\text { Total } \\
\text { Leucocyt. } \\
\text { Count/cmm }\end{array}$ & $\begin{array}{l}\text { Lymphocytes } \\
(\%)\end{array}$ & $\begin{array}{c}\text { Neutrophils } \\
(\%)\end{array}$ & $\begin{array}{l}\text { Monocytes } \\
(\%)\end{array}$ & $\begin{array}{c}\text { Eosinopils } \\
\%\end{array}$ \\
\hline Control & $6840 \pm 1166$ & $58 \pm 2.5$ & $43 \pm 2.5$ & $1.3 \pm 0.3$ & $0.0 \pm 0.00$ \\
\hline Green tea drinking & $5704 \pm 972$ & $41_{* *}^{ \pm} 4.5$ & $57 \underset{*}{ \pm} 4.9$ & $1.0 \pm 0.2$ & $0.1 \pm 0.3$ \\
\hline Carrageenan for 24 hours & $\begin{array}{c}16233 \pm 2932 \\
\text { ooo }\end{array}$ & $58 \pm 4.6$ & $\begin{array}{c} \pm 4.7 \\
0\end{array}$ & $\begin{array}{l} \pm 0.3 \\
* * *\end{array}$ & $\begin{array}{l} \pm 0.3 \\
* * *\end{array}$ \\
\hline $\begin{array}{c}\text { Green } \\
\text { tea+Carrageenan for } \\
24 \text { hours }\end{array}$ & $5050 \pm 746$ & $55 \pm 7.5$ & $43 \pm 7.0$ & $1.4 \pm 02$ & $\begin{array}{l} \pm 0.2 \\
* * *\end{array}$ \\
\hline $\begin{array}{l}\text { Carrageenan for } \\
72 \text { hours }\end{array}$ & $\begin{array}{c}10186 \pm 1269 \\
\text { ooo }\end{array}$ & $62+5.6$ & $\begin{array}{ll}37 \pm 5.8 \\
\\
0\end{array}$ & $\begin{array}{c}0.4 \pm 0.2 \\
\text { oo }^{*}\end{array}$ & $1.0+0.2$ \\
\hline $\begin{array}{c}\text { Green tea +Carrageenan for } \\
72 \text { hours }\end{array}$ & $4750 \pm 1062$ & $65 \pm \underset{0}{0} 5.9$ & $43 \pm 5.9$ & $0.8+0.3$ & $\begin{array}{l}+0.2 \\
. * * *\end{array}$ \\
\hline
\end{tabular}

Table (4): Bone marrow lymphocytic count, peripheral blood lympohocytic count and peritoneal fluid lymphocytic count from green tea drinking and Carrageenan-treated rats.

\begin{tabular}{|c|c|c|c|}
\hline Animal group & $\begin{array}{c}\text { Bone marrow } \\
\text { Lmphocytes } \\
\%\end{array}$ & $\begin{array}{c}\text { Peripheral blood } \\
\text { Lymphocytes } \\
\%\end{array}$ & $\begin{array}{l}\text { Peritoneal fluid } \\
\text { Lymphocytes } \\
\%\end{array}$ \\
\hline Control & $56 \pm 3.3$ & $58 \pm 2.5$ & $58 \pm 1.1$ \\
\hline Green tea drinking & $54 \pm 5.1$ & $64 \pm 4.0$ & $41 \underset{* *}{ \pm} 4.4$ \\
\hline Carrageenan for 24 hours & $64 \pm 2.6$ & $58 \pm 4.5$ & \pm 4.4 \\
\hline $\begin{array}{c}\text { Green tea+Carrageenan for } \\
24 \text { hours }\end{array}$ & $\begin{array}{c}116 \pm 7.3 \\
* * * \\
\ldots, 000\end{array}$ & $59 \pm 8.1$ & $55 \pm 7.5$ \\
\hline Carrageenan for 72 hours & $\begin{array}{c}76+5.2 \\
* * \\
\text { oo }\end{array}$ & $68 \underset{*}{ \pm} 7.6$ & $62 \pm 5.6$ \\
\hline $\begin{array}{c}\text { Green tea +Carrageenan for } \\
72 \text { hours }\end{array}$ & $\begin{array}{c}100 \pm 11.1 \\
\ldots * * \\
\ldots, \text {,ooo }\end{array}$ & $65 \pm 7.6$ & $56 \mathrm{o}^{ \pm 59}$ \\
\hline
\end{tabular}

$*, * *, * * * \quad$ Significance at $\mathrm{P}<0.05,0.01$ and 0.001 respectively when compared with control group

o,oo,ooo Significance at $\mathrm{P}<0.05,0.01$ and 0.001 respectively when compared with green tea drinking group .

Significance at $\mathrm{P}<0.05,0.01$ and 0.001 respectively when compared with

Carrageenan treated groups 
Table (5): Serum total protein albumin and globulin concentrations from green tea drinking and Carrageenan treated rats.

\begin{tabular}{|c|c|c|c|}
\hline Animal group & $\begin{array}{c}\text { Total protein conc. } \\
\text { Gm/dL }\end{array}$ & $\begin{array}{l}\text { Total Albumin } \\
\text { Con. Gm/dL }\end{array}$ & $\begin{array}{l}\text { Total globulin } \\
\text { Conc. Gm/dL }\end{array}$ \\
\hline Control & $8.0 \pm 0.4$ & $5.0 \pm 0.5$ & $2.6 \pm 0.39$ \\
\hline Green tea drinking & $6.8 \pm 0.24$ & $4.0 \pm 4.0$ & $2.8 \pm 0.26$ \\
\hline Carrageenan for 24 hours & $8.2 \pm 0.28$ & $\begin{array}{c}6.6 \pm 0.89 \\
\mathrm{o}\end{array}$ & $1.9 \pm 0.68$ \\
\hline $\begin{array}{c}\text { Green tea+Carrageenan for } \\
24 \text { hours }\end{array}$ & $7.8 \pm 0.57$ & $\begin{array}{c}6.7 \underset{* *}{ \pm 0.59} \\
\text { оoо }\end{array}$ & $\begin{array}{c} \pm 0.07 \\
* \\
\text { ooo }\end{array}$ \\
\hline Carrageenan for 72 hours & $6.8 \pm 0.30$ & $5.3 \pm 0.25$ & $\begin{array}{c} \pm 0.31 \\
*_{\mathrm{OoO}}\end{array}$ \\
\hline $\begin{array}{c}\text { Green tea }+ \text { Carrageenan for } \\
72 \text { hours }\end{array}$ & $6.2 \pm \underset{* *}{ \pm 0.94}$ & $\begin{array}{c}5.5 \pm 0.66 \\
\mathrm{o}\end{array}$ & $\begin{array}{c}0.76 \underset{* * *}{ \pm 0.47} \\
\text { оoо }\end{array}$ \\
\hline
\end{tabular}

Table (6):Serum total Immunoglobuline(G) concentrations from green tea drinking and Carrageenan treated rats.

\begin{tabular}{|c|c|}
\hline Animal group & Total protein conc. Gm/dL \\
\hline Control & $18288 \pm 2528$ \\
\hline Green tea drinking & $22200 \pm 2528$ \\
\hline Carrageenan for 24 hours & $15870 \underset{\text { ooo }}{+} 1027$ \\
\hline Green tea+Carrageenan for 24 hours & 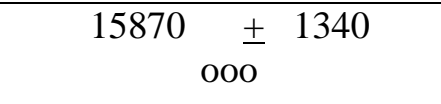 \\
\hline Carrageenan for 72 hours & $22450 \pm 1043$ \\
\hline Green tea +Carrageenan for 72 hours & 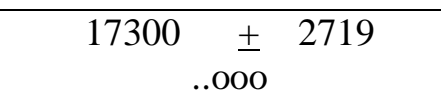 \\
\hline
\end{tabular}

$*, * *, * * * \quad$ Significance at $\mathrm{P}<0.05,0.01$ and 0.001 respectively when compared with control group

o,00,00o Significance at $\mathrm{P}<0.05,0.01$ and 0.001 respectively when compared with green tea drinking group .

Significance at $\mathrm{P}<0.05,0.01$ and 0.001 respectively when compared with Carrageenan treated groups 


\section{Maha G. Soliman}

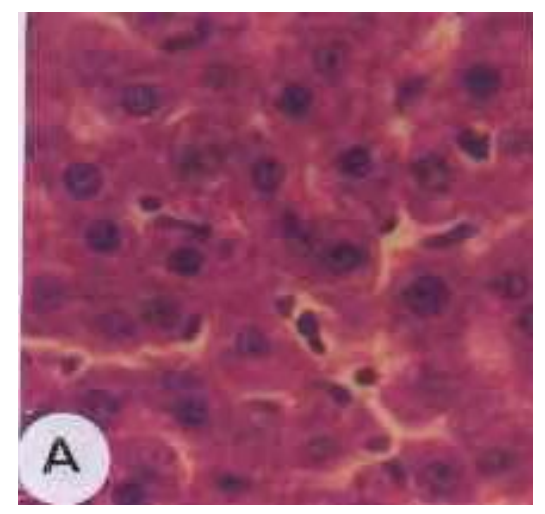

( H\&E X 400 )

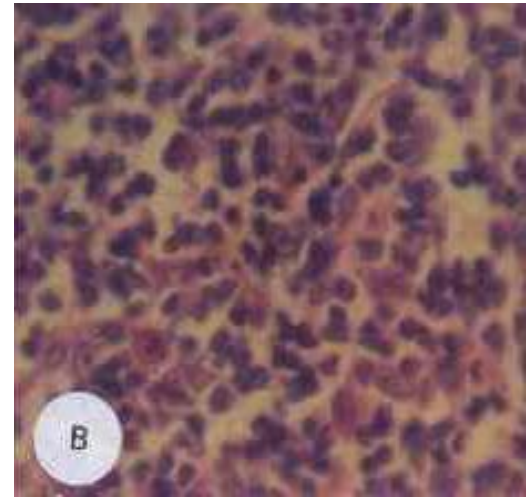

( H\&E X 200$)$

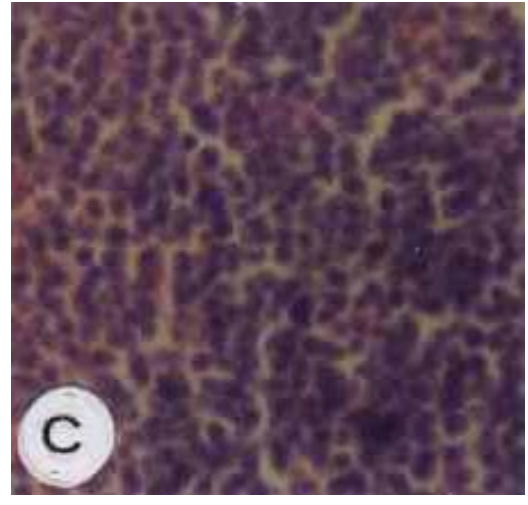

( H\&E X 200 )

Fig (1) : Histological sections in the liver (A), spleen (B) and thymus gland (C) green tea drinking group (H\&E) Note normal appearance of the different cells.

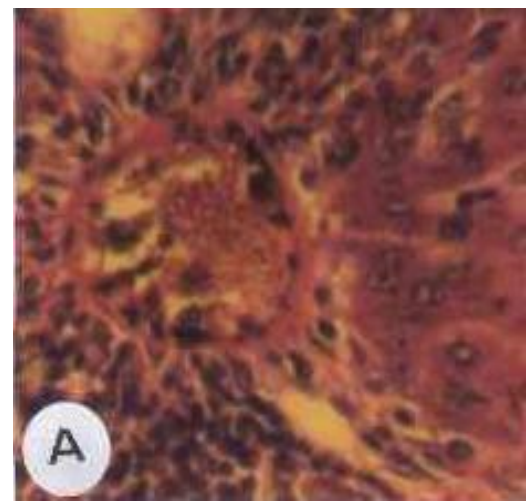

( H\&E X 400$)$

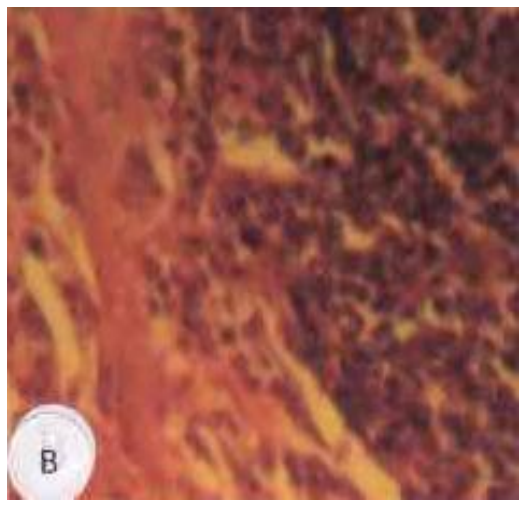

( H\&E X 200$)$

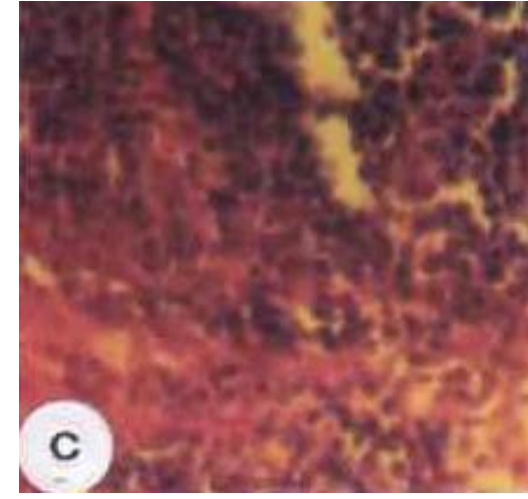

( H\&E X 200 )

Fig (2): Histological sections in the liver (A), spleen (B) and thymus gland (C) of Carrageenan treated group. Note many histopathological changes in liver, spleen and thymus gland.

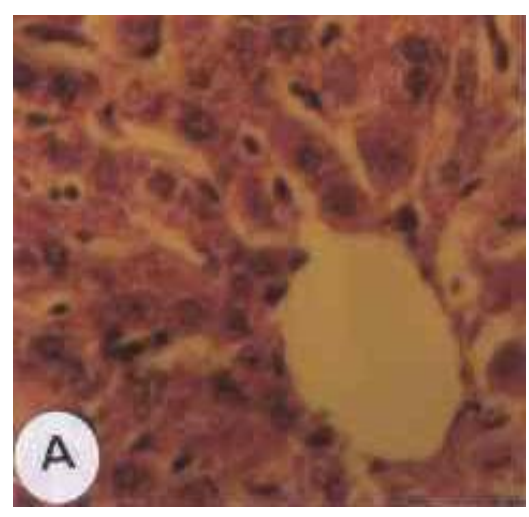

( H\&E X 400 )

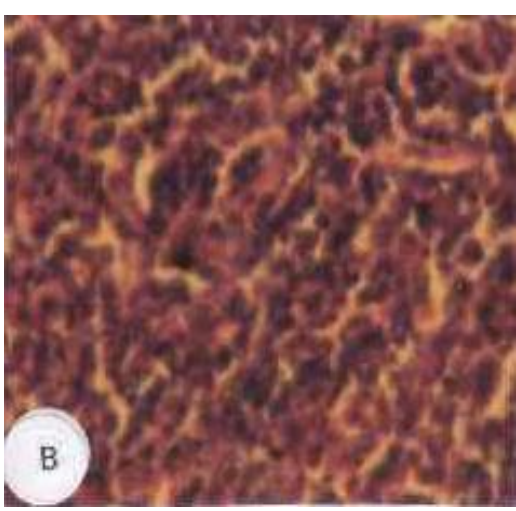

( H\&E X 200 )

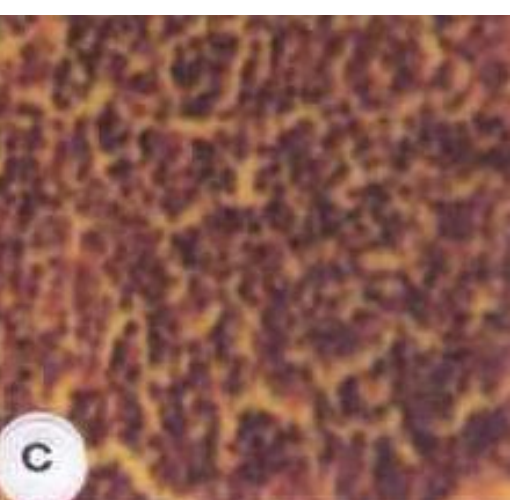

( H\&E X 200 )

Fig (3) : Histological sections in the liver (A), spleen (B) and thymus gland (C) of green teaCarrageenan treated group. Note: signs of improvement in the different tissues. 


\section{Result And Discussion}

Green tea is a popular beverage consumed world wide. The epicatechin derivatives, which are commonly called polyphenols which are the active ingr edients in green tea and possess antiox idant, anti-inflammatory and anti-carci nogenic properties. It seems that the green tea affects the immune system through immunomodulatory properties especially in peripheral blood mononuclear cells (Zvetkova et al., 2001). The green tea intake was associated with increased total leucocytic and lymphocytic counts associated with elevated level of serum globulin and serum IgG (Tables, 2,5 \& 6). Many studies have proved that green tea polyphenols inhibit inflammatory responses. Polyphenols block the acti vation of the transcription factor, $\mathrm{NF}_{\mathrm{k}} \mathrm{B}$, which plays a central role in numerous immunologic processes. $\mathrm{NF}_{-\mathrm{k}} \mathrm{B}$ controls the expression of a wide variety of genes active in inflammation including cytokines, enzymes, adhesion molecules and acute phase proteins (Varilek et al., 2001). Inhibitors of $\mathrm{NF}_{\mathrm{k}} \mathrm{B}$ have been shown to decrease inflammation in animal model (Neurath et al., 1996). These observations suggest that $\mathrm{NF}_{\mathrm{k}} \mathrm{B}$ is a suitable target to prevent or reduce an inflammatory response. The ability of green tea to inhibit $\mathrm{NF}_{-\mathrm{k}} \mathrm{B}$ activation and to decrease the level IL-2 production may be responsible in part for its anti-inflammatory effects (Varilek et al., 2001 and Wilasrumee, et al., 2002) . In this study an inflammatory model was induced by Carrageenan which is considered as a standard irritant for examining acute inflammation and anti-inflammatory drugs (Di Rosa, 1972). Animals injected intraperitonealy with Carrageenan have shown highly significant leucocytosis, monocytosis and eosinophilia. Also peritoneal fluid leucocytic counts and bone marrow lymphocytes were increased. Besides increased liver, spleen and thymus gland weights were recorded. The reticuloendothelial organs changes were more distinguished in the 72 hours animal group.

Polyphenols have been reported to exhibit anti-inflammatory properties. Therefore the effects of drinking green tea on the inflammatory reaction induced by Carrageenan after 24 and 72 hours were studied. A highly significant reduction in the total leucocytic count in the peripheral blood and peritoneal fluid was recorded .

Both monocytosis and eosinophilia were significantly corrected in peripheral blood and similar observations were recorded in the peritoneal fluid in green tea drinking-CGN group of both 24 and 72 hours groups .Also spleen and thymus weight percentages have shown relative modulation, besides a very highly significant increase in the bone marrow lymphocytic infiltration was recorded in the same previous groups. While a significant drop in the levels of serum globulin and IgG was reported in the green tea drinkingCarrageenan treated groups when compared with its corresponding Carrageenan treated groups and green tea drinking animal group. These changes may be explained by the immunosuppressive immunomodulatory action of green tea recorded by Wilasrusmee et al. (2000). Haggi et al. (1999), has mentioned that green teafed mice had lower levels of total and CII-specific IgG antibody, because the Th 1-type response (IFN- $\gamma$ producing) associated with the production of complement -fixing Ig G2a antibodies which are thought to bind with the cartilage and cause initial damage. They added that the level of total IgG antibodies in the arthritic joints of non- 
green tea-fed mice was markedly higher in comparison to the levels detected in the joints of green tea-fed mice. Similar results were obtained in the serum (Das et al., 2002) .

Intraperitoneal injection of Carrageenan also caused many histopa thological changes. The liver has shown severe inflammation, cellular lymphocytic infiltration, severly congested liver sinuses, Both fatty hydropic degeneration hepatocytes and necrosis in the liver was noticed. The spleen showed many necrotic areas, congested sinusoidal spaces filled with erythrocytes. Many degenerated cells with pyknotic nuclei were observed. Similar findings were observed in the thymus gland which showed severly congested area with erythrocytic infiltration mainly in the medulla, intralobular adipose tissue and intralober hyaline degeneration. Besides cortical region with degenerative changes in the cortex was observed. Fig. (2). These necrotic and degenerative changes of (CGN) injection animal groups were markedly improved in green tea-drinking animal groups. The green tea drinkingCarrageenan treated animals revealed normal hepatic lobules and most of the hepatocytes appeared normal and the inflammatory reaction was markedly reduced. Green tea acts as chemopreventive agent that can modulate apoptosis and thereby affected the steady state cell population(Das et al., 2002) Histopathological examination reveald effective protection against induction of hepatic degenerative changes. Fig.(3).

Green tea has been found to provide protection to the liver against a variety of toxic substances. (Sano et al., 1995 and Lau et al., 2002) .

On the other hand similar antiinflammatory histological response was observed in the spleen and thymus gland of green tea drinking-Carrageenan treated animal groups. Splenic red pulps were enriched with lymphoid cells. The thymus gland degenerative changes were much reduced under the effect of green tea and thymocytic cell counts were much preserved. This can be explained by the immuno protectiveimmuno modulatory effects of green tea (Zhu et al., 1997) and were also observed in this study in (Fig. 3)

The usefulness of tea polyphenols may be extended by combining them with other consumer products such as food items and vitamin supplements. It is concluded that green tea can play a role in adverse changes in immune function and acts as an anti-inflammtory agent.

\section{References}

1. Arteel, G.E.; Uesugi, T.; Bevan, L.N.; Gabele, E.; Wheeler, M.D.; Mckim, S.E. and Thurman, R.G.,(2002): Green tea extract protects against early alcohol induced liver injury in rats. Biol Chem.; 383 (3-4): 663-670.

2. Chan, M.M. Y.; HO,C.T. and Huang, H. I. (1995): Effects of three dietary phytochemicals from tea, rosemary and tumeric on inflammation-induced nitric production. Cancer Lett; 96:23-29.

3. Das, M.; Sur, P.; Gomes, A.; Vedasiromoni,J.R. andGanguly, D.K. (2002): Inhibition of tumour growth and inflammation by consumption of tea. Phytother Res;Mar;16 suppl.1:S 40-44.

4. DiRosa,M.(1972):Biological properties of carrageenan.J.Pharm;24:89-102.

5. Fajun.Y.; Willem. J.S.D.; Craig., M. and Gary, W.V.(1998): green tea polyphenol block endotoxin-induced tumor necrosis factor-production and lethality in a murine model .The journal of nutrition, 128:2334-2340.

6. Gary,W.v.;Fagum.Y.;Eun.Y.L.;Wille m,J.S.D.;Jian.,Z.;Heli. S.O.; Kenloch. F.W. and Craig.J.M. (2001): Green tea polyphenol extract attenuates inflammation in interleukin to-diffe cient mice, a model of autoimmunity . Journal of nutrition , 131:2034-2039.

7. Ghosh, A.K.; Hiraswa, N.; Niki, H. and Ohuchi, K. (2002): 
Cyclooxygenase-to-mediate angiogen esis in Carrageenan induced granulation tissue in rats. J.Pharmacol Exp. Therap; 295 (2); 802-809.

8. Haggi, T.M.; Anthony, D.D.; Gupta, S.;Ahmed,N.;Lee,M.S.;Kumar,G.K.a nd Muktar, H. (1999): Prevention of collagen-induced arthritis in mice by a polyphenolic fraction from green tea. Immunology; 96 (8):4524 4529.

9. Mukhtar,H. and Ahmed,N. (2000): Tea polyphenol: prevention of Cancer and optimizing health. American Journal of Clinical Nutrition, 71 (6): 1698-1702.

10. Hofbauer, R.; Frass, M.; Gmeiner, B.; Handler, S.; Speiser, W. and Kapio, S. (1999): The green tea extract epigallocatechin gallate is able to red uce neutrophil trans- migration through monolayers endothelial cells. Wien Klin wochenschr.Apr9;111(7):278-282.

11. Lau, K.M.; He, Z.D.; Dong, H.; Fung,K.P and But,P.P.(2002) : Antioxidative, anti-inflammatory and hepatoprotective effects of Ligustrum robustum. Ethnopharmacol, Nov;83(1-2):63463.

12. Lin, Y.L. and; Lin, J.K. (1997): (-)Epigallocatochin-3-gallate blocks the induction of nitric oxide synthase by down regulating lipopolysaccharideinduced activity of transcription factor nuclear factor-Kapp B. Mol pharmacol; 52:465-472.

13. Nacife, V.P.; Soeiro, M.D.; AraujoJorge, T.C.; Castro.; Neto, H.C. and Meirells, M.D. (2000): Ultrastructural, immunocytochemical and flow cytometry study of mouse peritoneal cells stimulated with carrageenan. Cell Struct. Funct; 25 (6):337-350.

14. Neurath, M.F.; Pettersson, S.; Meyer-Zum, K.H. and strober, W. (1996): Local administration of antisense phosphorothioate oligonucl edotides to the p65 subunit of NF- $\gamma$ B abrogates established experimental colites in mice. Nat. Med; 2:998-1004.

15. Sano, M; Takahashi, Y. and Yoshino, K. (1995): Effect of tea (Camellia sinensis) on Lipid peroxidation in rat liver and kidney : a comparison of green and black tea feeding. Biol. Pharm. Bull; 18:1006-1008.

16. Suganuma, M.; Okabe, S.; Sueoka, E.; Iida, N.; Komori, A.; Kim S, J. and Fujiki, H. (1996): A new process of cancer prevention mediated through inhibition of tumor necrosis factor $\alpha$ expression. Cancer Res; 56: 3711-3715.

17. Varilek, G.W.; Yang, F.; Lee, E.Y.; De Villers, J.S.; Zhong,J.; Helieh, S.; Westberry, F.K. and McClain, C.J. (2001): Green tea polyphenol extract atenuates inflammation in interleukin2-deficient mice, a model of auto immunity Journal of Nutrition; 131:2034-2039.

18. Wilasrusmee, C.; Sid diqui, J.; Bruch,D.; Wilasrs, S.and kittur, D.S. (2002): In vitro immunomodulatory effects of herbal products. Am. Surg. Oct; 860-864.

19. Yung , F.; Devillers, W.J.S.; Mc Clain, C. J. and Varilek, G.W.(1998): Green tea polyphenols block endotoxin-induced tumor necrosis factor -production and lethality in a murine model. The Journal of Nutrition; 128 (12): 2334-2340.

20. Zhu, M.; Gong, Y. and Ge, G.(1997): Effect of green tea on growth inhibition and immune regulation of lewis lung Cancer in mice. Zhonghua Yu Fang Yi Xue Za Zhi. Nov; 31(6):325-329.

21. Zhu, M.; Gong, Y. and Yang, Z.; (1998): Protective effect of tea on immune function in mice. Zhonghua $\mathrm{Yu}$ Fang Yi xue Za Zhi. Sep; 32(5):270-274.

22. Zhu, M.; Gong, Y.; Yong, Z.; Ge, G.; Han, C.; and Chen, J. (1999): Green tea and its major components ameliorate immune dysfunction in mice bearing lewis lung carcinoma and treated with the carcinogen NNK. Nutr cancer ; 35 (1):64-72.

23. Zvetkova, E.; Wirleitner, B.; Tram, N.T.; Schennach, H. and Fuchs, D. (2001): Aqueous extracts of Crinum Latifolium (L) and Camellia sinesis show immuno-mdulatory properties in human peripheral blood monouclear cells. Int. Immunopharmacol .Nov; 1(12):2143-2150. 


\title{
التغبيرات المناعية والهيستوليوجيه للمستخرج المائس كاميليا سايناسايس فى الجرذان المحدث بها الإلتهاب
}

\author{
مها غازى سليمان

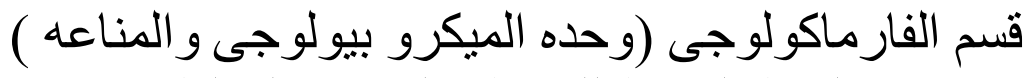 \\ الهيئة القومية للرقابة و البحوث الديكو ليولية
}

يهدف هذا البحث الى در اسه تأثير المستخرج المائى للثاى للاخضـر ( كاميليا

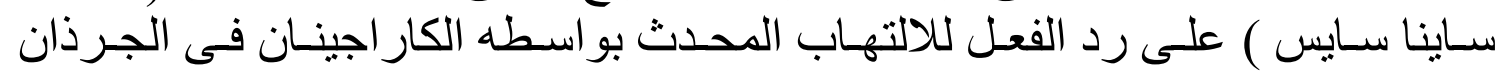

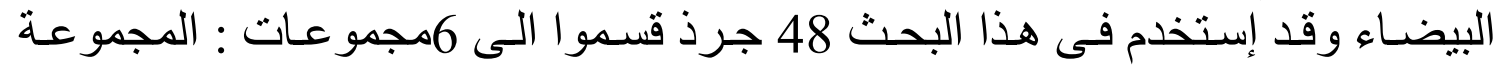

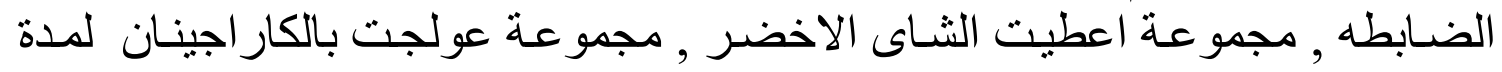

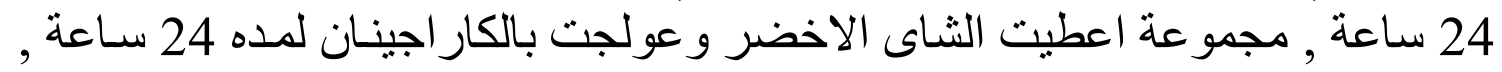

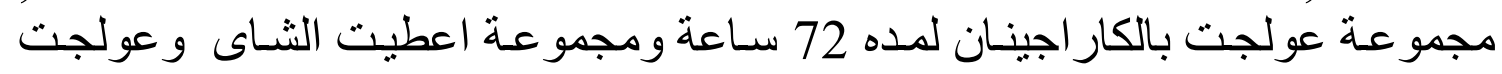

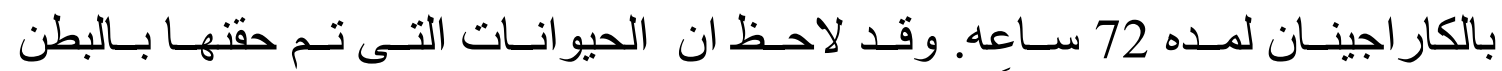

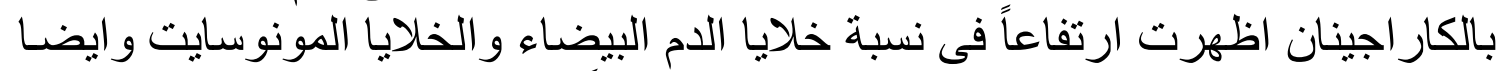

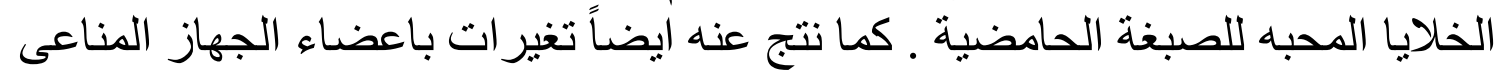

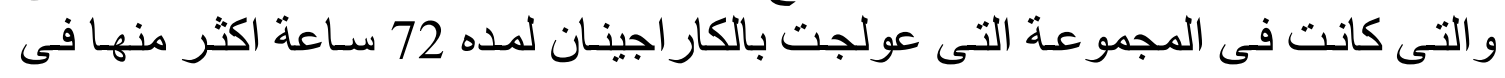

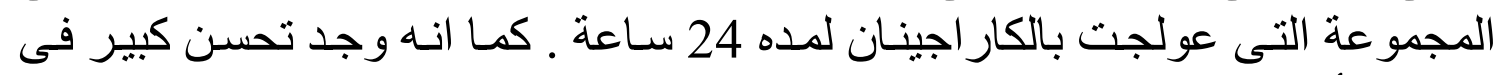

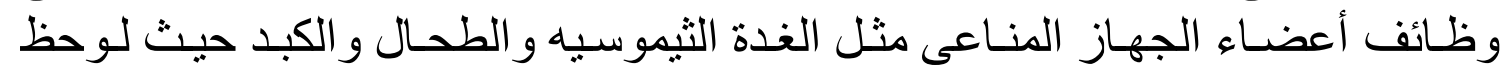

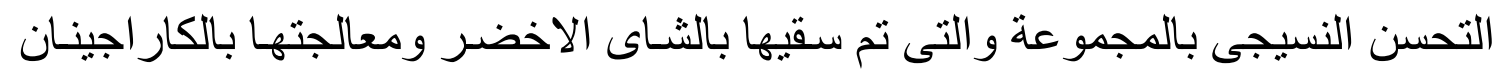

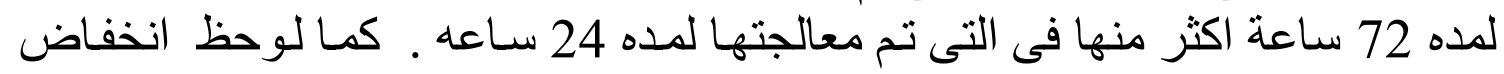

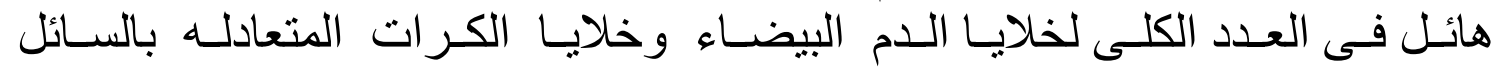

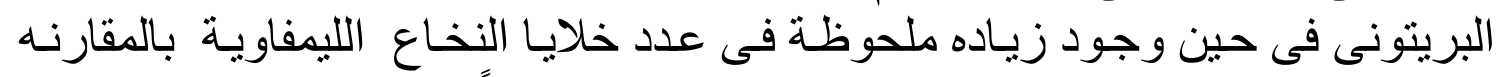

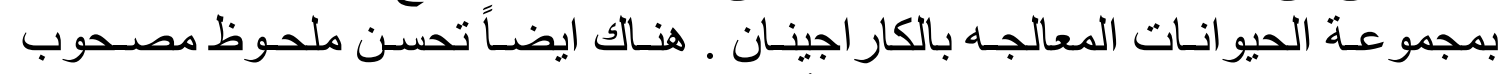

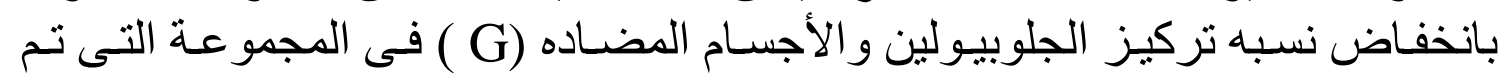

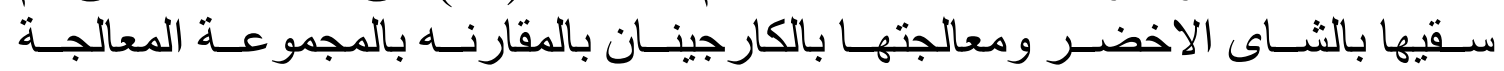

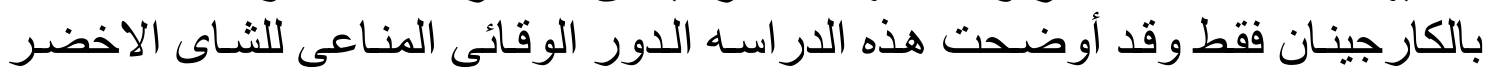

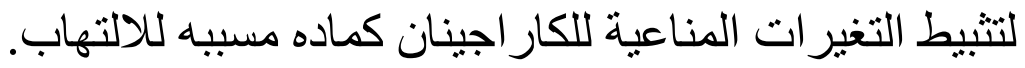

